\title{
Kekasaran dan Morfologi Hasil Pengelasan TIG Baja Tahan Karat 316 dengan Kadar Sulfur Berbeda
}

\author{
Abdullah Shahab \\ Jurusan Teknik Mesin- FTI, Institut Teknologi Sepuluh November, Surabaya \\ E-mail: shahab_nqa@yahoo.com
}

\begin{abstract}
ABSTRAK
Keberadaan elemen impuritis dalam baja tahan karat seringkali tanpa diduga bisa menimbulkan masalah dalam pengelasan. Perbedaan dengan kadar yang sangat kecil elemen impuritis, seperti sulfur, dari sebuah heat ke heat yang lain, bisa menimbulkan kesulitan terutama pada pengelasan secara otomatis. Penelitian ini bertujuan untuk melihat pengaruh kadar sulfur baja terhadap pembentukan morfologi lasan yang ditunjukkan dengan perbedaan kekasaran permukaan dan pembentukan kolam lasan yang berbeda. Pengaruh kadar sulfur terhadap kekasaran permukaan kolam lasan dipelajari dengan mengadakan pengelasan Tungsten Inert Gas baja tahan karat 316 dengan kadar sulfur yang berbeda. Variasi morfologi kolam lasan, penetrasi (P) dan lebar (L) kolam lasan dan rasio P/L dikaitkan dengan kekasaran permukaan. Pengaruh sulfur dipelajari juga dengan peleburan dengan arus dan durasi penyalaan yang bervariasi. Pengaruh sulfur ditunjukkan dengan variasi diameter kolam lasan berbentuk lingkaran dan juga pada derajat tonjolan yang mencuat dari bawah spesimen. Hasil penelitian menunjukkan bahwa kekasaran permukaan baja sulfur tinggi selalu lebih besar dibanding baja sulfur rendah. Arah aliran cairan yang berbeda diajukan untuk menjelaskan fenomena ini. Kekasaran yang lebih besar ini diikuti dengan harga P/L yang lebih berarti. Pengamatan pada hasil peleburan dengan busur stasioner menghasilkan kesimpulan yang menarik. Pengaruh sulfur dalam menentukan morfologi kolam lasan lewat fenomena arah aliran cairan hanya berlaku pada rentang tertentu parameter penyalaan busur. Pada rentang yang lain, morfologi kolam lasan lebih banyak ditentukan oleh karakteristik busur, seperti anode spot, ketimbang arah aliran cairan.
\end{abstract}

Kata kunci: Pengelasan TIG; baja tahan karat 316; sulfur; morfologi lasan; anode spot.

\begin{abstract}
The presence of impurities in stainless steel can unexpectedly create a problem in welding. The difference of a small amount of impurities, from heat to heat, can induce the inconsistency in welding especially in automatic welding. This study is conducted to asses the influence of sulfur content of the steel on morphology of weld which is represented by the variation of weld pool and surface roughness of weld. The effect of sulfur on surface roughness of weld is studied in TIG welding of 316 stainless steels with different sulfur content. The influence of sulfur on the weld geometry, characterized by the ratio of depth and width of the weld $(D / W)$, is studied in welding with various parameters. The variation of the weld geometry is conjointly studied in relation to the surface roughness of weldment. The effect of sulfur is also studied using a stationary arc with different current and duration. The variation of the diameter of a circular pool and the degree of protuberance which possibly emerged beneath the specimen is related to the sulfur content of the steel. The results of the study show the salient effect of sulfur on the surface roughness of weld. The surface roughness of steel with high sulfur content always more perturbed than that of steel with lower one; the different movement of liquid, characteristic of these two steels is posited to explain the difference. Greater degree of roughness is accompanied by a greater value of the ratio $D / W$. The results of the study with stationary arc show some points of a paramount importance. The effect of sulfur which hitherto considered advantageous to the formation of a weld with a higher ratio of $D / W$, turn out to be effective only in a specific range of welding parameters. In a different range, the weld geometry is more influenced by the arc characteristic, the anode spot.
\end{abstract}

Keywords: TIG welding; 316 stainless steel; sulfur; weld geometry; anode spot. 


\section{PENDAHULUAN}

Pembentukan kolam lasan ditentukan oleh gaya-gaya yang timbul pada saat pengelasan. Dikenal beberapa gaya yang menentukan, yaitu tekanan, olakan, dan aliran cairan dalam kolam lasan. Keseimbangan aliran dalam kolam lasan ini ditentukan oleh gaya akibat tekanan busur, gaya gravitasi, gaya elektromagnetik, dan gaya akibat tegangan permukaan $[1,2]$.

Dari sekian banyak gaya yang bekerja pada pembentukan kolam lasan, gaya elektromagnetik dan gaya akibat tegangan permukaan merupakan gaya-gaya yang paling berpengaruh dalam menentukan morfologi kolam lasan [3,4]. Pengaruh dari gaya-gaya ini ditentukan juga oleh parameter pengelasan yang digunakan $[5,6]$.

Penelitian yang dilakukan dengan menggunakan beberapa jenis material menunjukkan bahwa material yang memiliki tegangan permukaan yang tinggi menghasilkan penetrasi yang tidak dalam. Material dengan tegangan permukaan yang tinggi menunjukkan gradien termal tegangan permukan yang negatif [7]. Gradien termal tegangan permukaan positif bisa diperoleh dengan cara menambahkan elemen tensioaktif seperti sulfur ke dalam bahan. Penambahan elemen tensio-aktif ini bisa menurunkan tegangan permukaan dan pada arus tertentu bisa menimbulkan gradien termal positif. Perubahan gradien termal ini bisa merubah arah dari olakan cairan dan akan menghasilkan penetrasi yang lebih dalam. Penelitian yang dilakukan pada baja menunjukkan bahwa arah dan besar dari gaya akibat tegangan permukaan ditentukan oleh kandungan sulfur [8,9]. Aliran ke arah dalam kolam lasan juga terjadi ketika kandungan oksigen dalam kolam lasan mencapai lebih dari 100 ppm [10,11].

\section{Aliran Cairan dalam Kolam Lasan}

Gerakan cairan dalam kolam lasan memegang pengaruh yang berarti dalam menentukan morfologi kolam lasan. Pada saat kolam lasan mengandung jumlah yang cukup elemen tensio-aktif, gerakan dari cairan akan mengarah ke tengah dan akan menghasilkan kolam lasan yang sempit dan dalam. Sebaliknya ketidakhadiran elemen tensio-aktif akan memicu pergerakan cairan logam ke arah luar dan akan menghasilkan kolam lasan yang lebar dan dangkal.

Penelitian telah dilakukan untuk menunjukkan adanya gerakan cairan dalam kolam lasan ini dengan melakukan pengelasan Tungsten Inert Gas dengan arus denyut [12]. Karakteristik permukaan lasan yang berbeda dikaitkan dengan pengaruh kadar sulfur di dalam baja.

Gambar 1 menunjukkan front solidifikasi hasil pengelasan baja tahan karat dengan kandungan sulfur berbeda. Bisa diamati bahwa topologi permukaan hasil pengelasan sangat berbeda satu dengan yang lain. Perbedaan topologi permukaan ini merupakan akibat dari perbedaan gerakan yang khas untuk kedua buah material ini, yaitu gerakan kearah dalam pada pengelasan baja dengan sulfur tinggi (Gambar 1a), dan gerakan kearah luar pada pengelasan baja dengan sulfur rendah (Gambar 1b).

Gambar 2 menunjukkan secara skematis front solidifikasi terkait dengan posisi sesaat dari obor las pada pengelasan menggunakan arus denyut. Ketika obor pada posisi I, kolam lasan yang terbentuk akibat pemberian arus tinggi, Ia, membeku dan mencapai front solidifikasi $\mathrm{ABC}$ pada akhir dari periode rendah dari arus, $\mathrm{Tb}$. Penggunaan arus tinggi kembali pada posisi 1 menimbulkan tekanan busur dan memaksa cairan yang belum membeku bergerak membentur batas kolam lasan. Gerakan dari cairan ini, ketika membentur front solidifikasi $\mathrm{ABC}$, meleburkan front ini, membentuk front baru DEF, dan memicu luapan cairan yang menghasilkan front solidifikasi DGF.

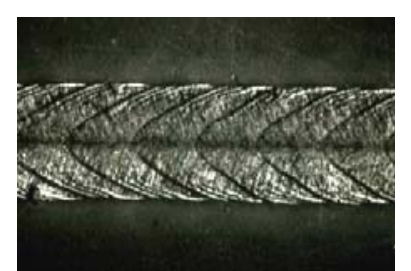

(a) Sulfur tinggi

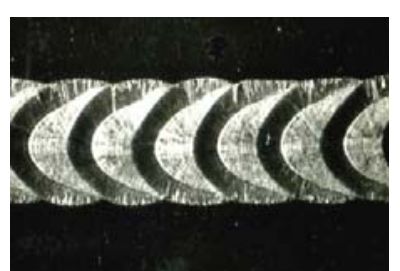

(b) Sulfur rendah
Gambar 1. Topologi Permukaan Baja pada Pengelasan dengan Arus Denyut [12]

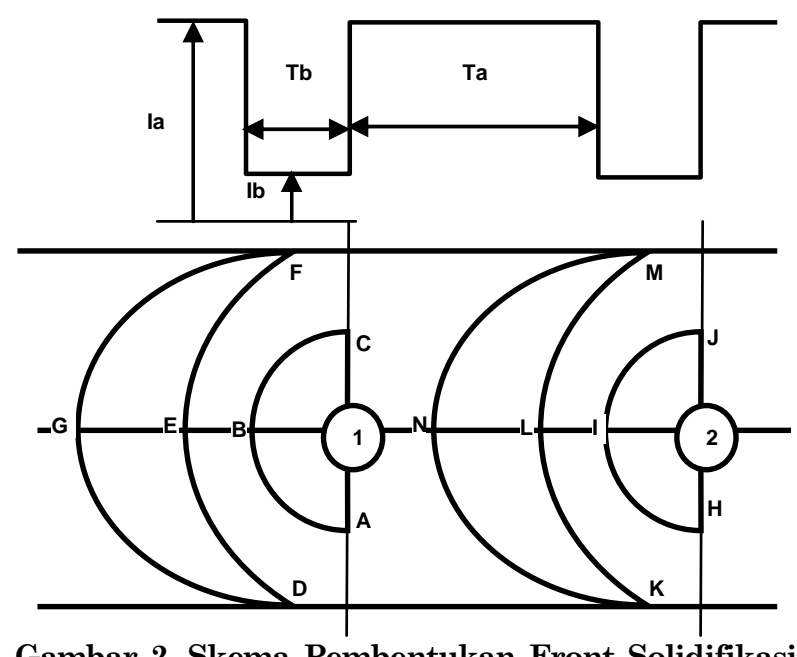

Gambar 2. Skema Pembentukan Front Solidifikasi pada Pengelasan dengan Arus Denyut

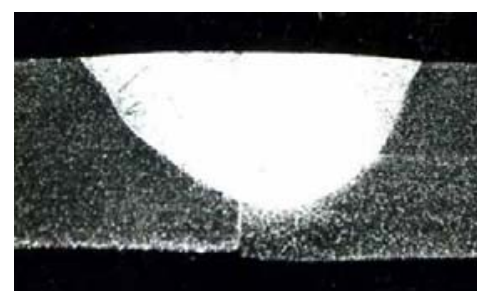

Gambar 3. Pembentukan Kolam Lasan tidak Simetris pada Pengelasan Baja [12] 
Gerakan obor diteruskan dan mencapai posisi 2 pada akhir dari fase rendah dari arus, Ib. Gerakan obor las dari posisi 1 menuju posisi 2 diikuti secara simultan dengan solidifikasi secara terus menerus kolam lasan yang terbentuk akibat arus tinggi pada posisi 1. Solidifikasi mencapai front solidifikasi sementara HIJ pada pada saat arus kembali ke level tinggi. Gerakan cairan yang dipicu oleh tekanan busur pada posisi 2 menyebabkan peleburan front solidifikasi HIJ, dan membentuk front solidifikasi baru KLM. Pembentukan front solidifikasi KLM ini diikuti dengan luapan cairan yang mengarah pada terbentuknya front solidifikasi KNM. Peristiwa ini berjalan terus menerus dan menghasilkan pembentukan dua front yang berbeda untuk tiap-tiap siklus arus seperti tampak pada gambar.

Perbedaan arah aliran cairan sebagai fungsi dari kadar sulfur juga ditunjukkan dengan pengelasan butt joint dua buah pelat baja dengan kadar sulfur yang berbeda [12]. Ketika pengelasan butt joint dilakukan pada baja dengan kadar sulfur berbeda, kolam las yang terbentuk menjadi miring dan condong menuju baja dengan tegangan permukaan yang lebih besar, yaitu baja dengan kadar sulfur lebih rendah (gambar 3). Perlu diketahui bahwa pengelasan ini dilakukan berulang kali-dengan hasil yang sama-dengan menjaga posisi obor las tegak lurus dan tepat pada garis pengelasan, sehinga bentuk tidak simetris ini tidak bisa diatribusikan oleh kesalahan penempatan obor las atau yang lain.

\section{Tegangan Permukaan dan Kandungan Sulfur}

Tegangan permukaan cairan adalah suatu gaya kontraksi permukaan yang menyebabkan tetes-tetes cairan memiliki bentuk mendekati bola dan menghasilkan permukaan yang paling sempit. Secara umum, tegangan permukaan cairan turun dengan peningkatan temperatur. Namun, pada saat kandungan sulfur di dalam bahan cukup besar, peningkatan temperatur dalam suatu rentang tertentu bisa meninggikan tegangan permukaan. Tegangan permukaan baja tahan karat 316 dengan kadar sulfur tinggi dan rendah dipelajari sebagai fungsi temperatur [12]. Hasil pengukuran ditunjukkan pada Gambar 4.

Bisa dilihat pada gambar bahwa bahan dengan kandungan sulfur lebih tinggi menunjukkan tegangan permukaan yang lebih rendah untuk berbagai harga temperatur. Sehubungan dengan gradien termal tegangan permukaan, bisa diamati bahwa baja dengan kandungan sulfur lebih tinggi menampilkan gradien termal positif, yaitu tegangan permukaan cairan naik dengan kenaikan temperatur. Tegangan permukaan lebih rendah dan gradien termal positif ini memicu aliran cairan logam menuju interior kolam lasan yang dengan demikian cenderung menghasilkan penetrasi yang lebih dalam.

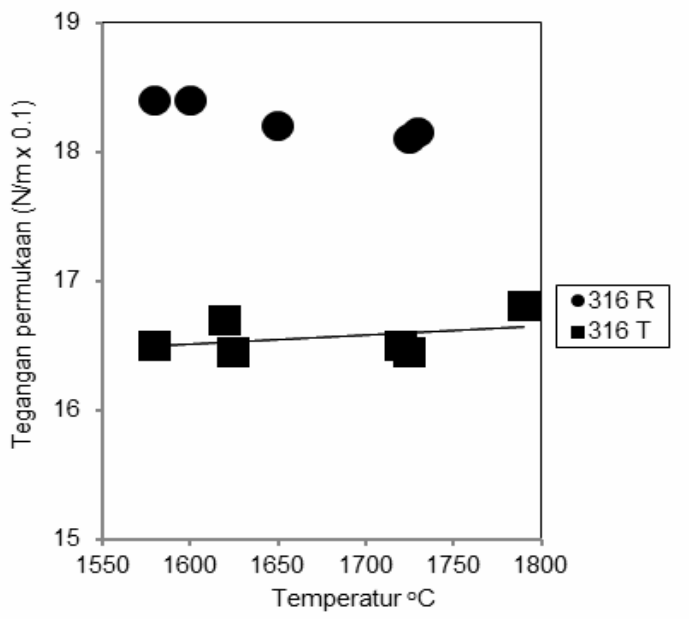

Gambar 4. Pengaruh Temperatur pada Tegangan Permukan Baja [12]

\section{Tujuan Penelitian}

Penelitian bertujuan untuk melihat pengaruh komposisi kimia baja tahan karat 316 terhadap kondisi kekasaran permukaan hasil pengelasan. Perbedaan kekasaran permukaan dikaitkan terutama dengan kandungan sulfur-elemen tensioaktifdalam baja. Elemen tensioaktif adalah elemen yang cenderung menempatkan dirinya pada permukaan cairan logam. Kehadiran elemen ini, pada rentang temperatur tertentu, mampu merubah gradien termal tegangan permukaan dan berakibat pada perubahan arah aliran cairan dalam kolam lasan.

Pengaruh variasi parameter pengelasan terhadap perubahan morfologi lasan baja dengan kandungan sulfur berbeda juga dipelajari dalam penelitian ini. Perubahan morfologi lasan ditunjukkan terutama pada perbandingan antara penetrasi (P) dan lebar (L) atau harga $\mathrm{P} / \mathrm{L}$ dari lasan. Pengaruh sulfur dalam baja dipelajari juga dengan pengamatan morfologi kolam lasan yang diperoleh pada peleburan dengan busur stasioner.

Penelitian ini juga berupaya untuk melihat sampai seberapa jauh pengaruh dari elemen tensioaktif dalam menentukan pembentukan kolam lasan. Keberadaan elemen tensio-aktif yang sejauh ini selalu dianggap berpengaruh positif terhadap peningkatan rasio $\mathrm{P} / \mathrm{L}$ ditinjau kembali dengan mempertimbangkan pengaruh dari parameter pengelasan yang terkait.

\section{METODE PENELITIAN}

Studi pengaruh komposisi kimia, terutama pengaruh sulfur terhadap perubahan kekasaran permukaan hasil pengelasan dipelajari dengan mengadakan pengelasan pada baja tahan karat 316 . Tersedia 2 macam baja dengan komposisi kimia yang relatif hampir sama, kecuali kandungan sulfur yang memang sengaja divariasikan. Digunakan baja 
tahan karat 316 dengan sulfur tinggi (316T) dan baja tahan karat 316 dengan sulfur rendah (316R) dengan kadar sulfur masing-masing $0.006 \%$ dan $0.001 \%$ berat. Percobaan pengelasan dilakukan pada baja dengan ketebalan $2 \mathrm{~mm}$. Secara lengkap komposisi kimia baja tahan karat 316 ini ditunjukkan pada Tabel 1.

Pada pengelasan dengan busur berjalan yang ditujukan untuk pengamatan kekasaran permukaan dan rasio penetrasi dan lebar lasan, $\mathrm{P} / \mathrm{L}$, percobaan pengelasan dilakukan dengan membuat pengelasan sepanjang spesimen menggunakan metode "bead on plate." Pengelasan dilakukan dengan melewatkan obor diatas spesimen untuk menghasilkan peleburan dan pembekuan tanpa penambahan logam pengisi.

Pengamatan terhadap topologi permukaan lasan dilakukan dengan cara melewatkan suatu stylus yang peka pada permukaan hasil pengelasan. Fluktuasi yang terjadi akibat kekasaran permukaan diamplifikasi dan digambarkan pada sebuah kertas. Untuk kepentingan ini digunakan peralatan pengukuran kekasaran permukaan yang biasa digunakan untuk menentukan kekasaran permukaan hasil proses perautan.

Tabel 2 menunjukkan parameter pengelasan yang umum digunakan dalam percobaan. Penggunaan parameter yang berbeda, apabila dibutuhkan, akan disebutkan pada pembahasan terkait.

Pada pengelasan dengan busur diam, spesimen baja tahan karat 316 dengan kandungan sulfur yang berbeda disiapkan dengan ukuran $3 \times 3 \mathrm{~cm}$. Arus dan durasi penyalaan busur diatur sesuai dengan yang diinginkan. Respon yang diamati untuk peleburan dengan busur diam ini adalah diameter kolam lasan, dan panjang terjauh dari tonjolan yang menjorok keluar dari bawah spesimen apabila hal itu terjadi.

Tabel 1. Komposisi kimia Baja Tahan Karat 316 Kadar Sulfur Berbeda

\begin{tabular}{ccccccccc}
\hline & $\mathrm{C}$ & $\mathrm{Si}$ & $\mathrm{Mn}$ & $\mathrm{P}$ & $\mathrm{S}$ & $\mathrm{Cr}$ & $\mathrm{Ni}$ & $\mathrm{Mo}$ \\
\hline $316 \mathrm{~T}$ & .06 & .47 & .82 & .028 & .006 & 17.55 & 11.83 & 2.25 \\
$316 \mathrm{R}$ & .05 & .54 & .84 & .024 & .001 & 17.58 & 11.74 & 2.07 \\
\hline
\end{tabular}

Tabel 2. Kondisi pengelasan umum

\begin{tabular}{ll}
\hline Polaritas & Lurus \\
Gas Proteksi & Argon \\
Debit Gas & 12 1/menit \\
Elektrode & Thoriated Tungsten \\
Diameter Elektrode & $3.2 \mathrm{~mm}$ \\
Sudut Elektrode & $30^{\circ}$ \\
Jarak Elektrode spesimen & $1.6 \mathrm{~mm}$ \\
Electrode Stickout & $4.4 \mathrm{~mm}$ \\
Diameter nozzle & $10 \mathrm{~mm}$ \\
\hline
\end{tabular}

\section{HASIL DAN PEMBAHASAN}

\section{Kekasaran Permukaan Hasil Pengelasan}

Pengaruh kandungan sulfur pada pengelasan baja 316 dipelajari dengan mengadakan pengelasan dengan kombinasi arus dan kecepatan pengelasan. Dalam penelitian ini digunakan arus 60, 75, dan 100 A, dengan kecepatan pengelasan 15,22 , dan 35 $\mathrm{cm} /$ menit.

Pengaruh kandungan sulfur terhadap kekasaran permukaan lasan diamati dengan melakukan analisa kekasaran permukaan pada hasil pengelasan baja dengan kandungan sulfur berbeda. Agar tidak menimbulkan kerancuan dengan hasil penelitian yang disajikan pada bab pendahuluan dan topologi permukaan pada Gambar 1, perlu diketahui bahwa permukaan yang diuji ini adalah permukaan yang dihasilkan pada pengelasan tanpa arus denyut dengan jarak sangat terbatas dan tidak mencakup topologi secara keseluruhan. Beberapa sampel hasil pengelasan yang dilas dengan berbagai parameter ditunjukkan pada gambar 5 . Kekasaran permukaan yang ditampilkan pada Gambar 5 ini merupakan replika hasil penggambaran ulang; hal ini dilakukan karena kualitas gambar yang kurang memadai yang diperoleh langsung dari peralatan. Secara umum bisa dilihat bahwa permukaan lasan baja dengan kandungan sulfur tinggi, baja 316T, menunjukkan permukaan yang lebih berombak. Permukaan hasil pengelasan baja dengan kandungan sulfur lebih rendah, baja 316R, menunjukkan permukaan yang lebih halus. Perbedaan arah aliran cairan dari kedua baja ini bisa merupakan penyebab dari perbedaan tingkat kekasaran tersebut. Aliran cairan ke arah dalam pada pengelasan baja dengan sulfur tinggi membentur aliran akibat tekanan busur dan memicu terjadinya turbulensi cairan yang mengakibatkan penampakan lebih jelas dari alur-alur solidifikasi.

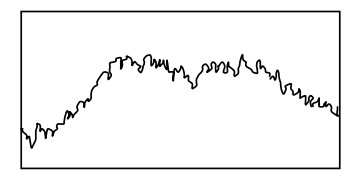

a. $316 \mathrm{~T}$, Arus $60 \mathrm{~A}, \mathrm{~V} 15 \mathrm{~cm} / \mathrm{menit}$

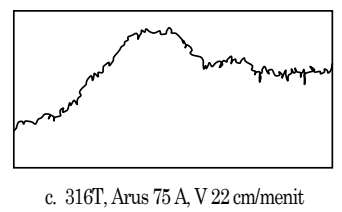

Gambar 5. Kekasaran Permukaan Lasan pada Pengelasan Baja 
Dari data hasil percobaan diamati adanya kaitan antara kekasaran permukaan dan aspek geometri kolam lasan. Permukaan dengan kekasaran yang lebih besar menghasilkan penetrasi yang lebih dalam dan harga P/L yang lebih besar. Sebagai contoh, Gambar 5a menunjukkan kekasaran permukaan lasan baja dengan kadar sulfur tinggi yang menghasilkan rasio P/L 0.67; sedangkan Gambar 5b menunjukkan kekasaran permukaan lasan baja dengan kadar sulfur rendah yang menghasilkan rasio $\mathrm{P} / \mathrm{L}$ 0.41.

Pengaruh sulfur dalam menentukan morfologi lasan pada variasi parameter yang digunakan ditunjukkan pada Gambar 6 dalam bentuk diagram balok. Sebagai respon digunakan hasil perbandingan antara penetrasi dan lebar pengelasan, P/L, yang merepresentasikan bentuk dari kolam lasan. Gambar 6 menunjukkan dengan jelas bahwa harga $\mathrm{P} / \mathrm{L}$ untuk pengelasan baja dengan kadar sulfur tinggi selalu lebih besar ketimbang nilai P/L baja dengan sulfur rendah. Hal ini menunjukkan pengaruh sulfur dalam pembentukan kolam lasan yang sempit dan dalam. Gambar makrostruktur kolam lasan dalam dan sempit (P/L besar) dan kolam lasan dangkal dan lebar (P/L kecil) ditunjukkan pada Gambar 7.

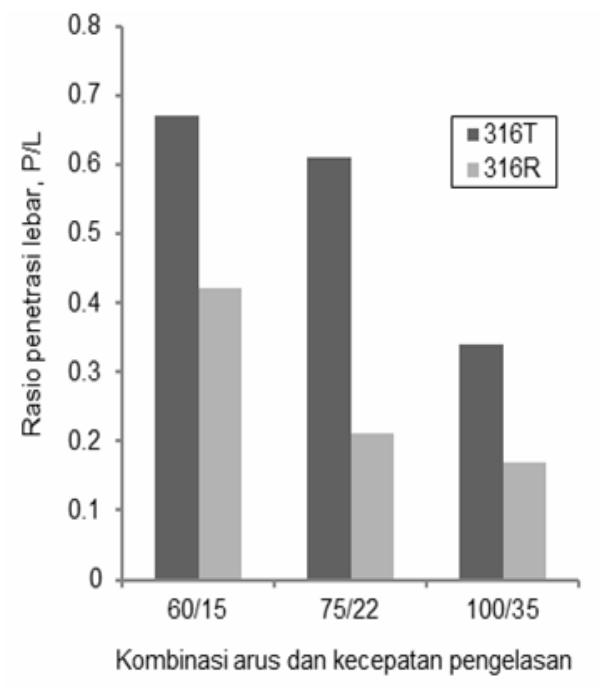

Gambar 6. Pengaruh Kadar Sulfur pada Rasio P/L

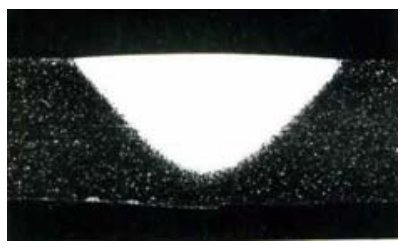

(a) kolam lasan sempit dan dangkal, P/L kecil

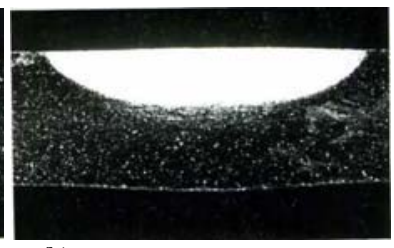

(b) kolam lasan lebar dan dalam, $\mathrm{P} / \mathrm{L}$ besar
Gambar 7. Makrostruktur Kolam

\section{Peleburan dengan Mengunakan Busur Diam}

Busur lasan yang dipertahankan diam pada material akan menghasilkan suatu kolam lasan peleburan yang berbentuk menyerupai lingkaran. Pengaruh dari parameter, arus dan waktu peleburan, dan komposisi kimia baja dalam pembentukan kolam lasan berbentuk lingkaran ini dievaluasi dengan pengukuran diameter lingkaran dan juga dengan melihat level dari tonjolan yang mencuat dari bagian bawah spesimen-membentuk kubah-ketika kolam lasan runtuh dan merosot kebawah spesimen.

Percobaan dilakukan pada baja tahan karat 316 dengan kandungan sulfur yang berbeda dengan menggunakan arus 50,60, 70, dan $80 \mathrm{~A}$, dengan durasi penyalaan berkisar antara 2 sampai 16 detik tergantung arus yang digunakan. Durasi penyalaan lebih panjang hanya bisa digunakan pada arus yang lebih rendah; penggunaan pada arus lebih tinggi akan melubangi spesimen. Gambar 8 menunjukkan perubahan diameter lingkaran kolam lasan sebagai fungsi dari waktu penahanan busur pada arus $50 \mathrm{~A}$.

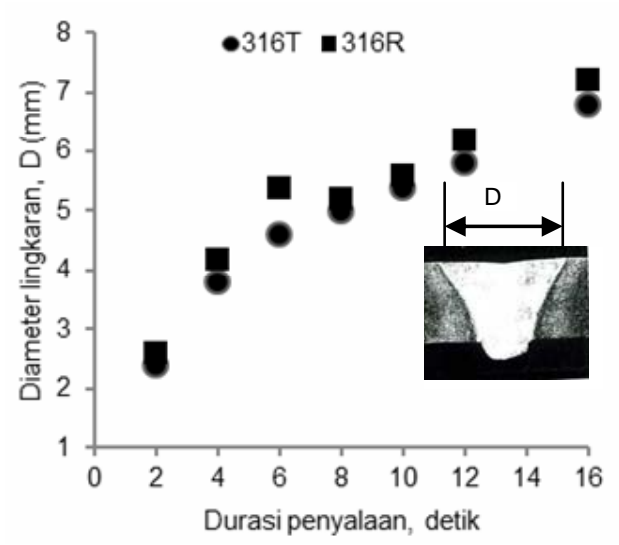

Gambar 8. Diameter Lingkaran Kolam Lasan Hasil Penyalaan Busur pada Arus 50A

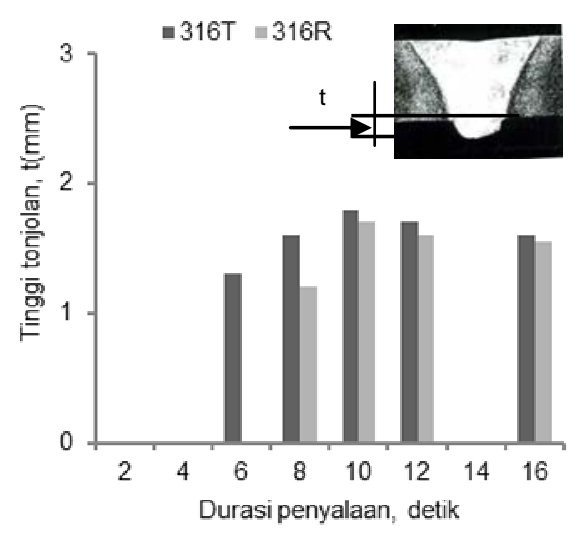

Gambar 9. Tinggi Tonjolan di Bawah Spesimen Kolam Lasan Hasil Penyalaan Busur pada Arus 50 A 
Pengamatan pada Gambar 8 menunjukkan bahwa peningkatan durasi penyalaan busur menghasilkan diameter kolam lasan yang lebih besar, yang dialami baik pada baja dengan sulfur tinggi maupun baja dengan sulfur rendah. Peningkatan ini bisa dijelaskan dengan peningkatan pasokan panas yang terjadi pada penyalaan busur dalam waktu yang lebih lama.

Pada saat arus pengelasan relatif rendah, $50 \mathrm{~A}$, diameter kolam lasan baja dengan sulfur tinggi secara sistematis lebih kecil dari diameter kolam lasan baja dengan sulfur rendah. Kedalaman dari hasil pengelasan selalu menunjukkan penetrasi yang lebih besar.

Tonjolan atau kubah yang mencuat keluar dari bagian bawah spesimen terjadi pertama kali pada baja dengan sulfur tinggi (Gambar 9). Tonjolan yang pertama muncul dibawah spesimen terjadi ketika penyalaan busur ditahan selama durasi 6 detik. Penyalaan busur pada durasi 2 dan 4 detik belum menimbulkan tonjolan dibawah spesimen, artinya panas yang diberikan belum cukup untuk menghasilkan penetrasi yang mampu menembus spesimen. Level tonjolan yang lebih besar pada baja dengan sulfur yang lebih tinggi ini bisa diamati pada berbagai harga durasi penyalaan busur.

Pada penggunaan arus yang lebih besar dari 50 A, diameter kolam lasan baja sulfur tinggi yang pada awalnya lebih kecil, berbalik arah menjadi lebih besar ketika waktu penyalaan busur mencapai harga tertentu. Diameter yang lebih besar ini diikuti dengan tonjolan lebih kecil pada bagian bawah kolam lasan. Fenomena ini tampak pada peleburan dengan arus 60,70, dan $80 \mathrm{~A}$. Hasil penyalaan busur dengan arus $80 \mathrm{~A}$ ditunjukkan pada gambar 10 dan 11 masing-masing untuk diameter lingkaran kolam lasan dan tonjolan pada bagian bawah spesimen. Tampak pada Gambar 10 bahwa pada saat durasi penyalaan busur dibawah 4 detik, diameter logam baja $316 \mathrm{~T}$ sedikit lebih kecil ketimbang diameter baja 316R. Namun, ketika durasi penyalaan busur diatas 4 detik, diameter lingkaran baja $316 \mathrm{~T}$ berubah menjadi sedikit lebih besar daripada diameter baja 316R. Fenomena perubahan tren pengaruh sulfur ini tampak lebih jelas pada Gambar 11. Pengamatan pada Gambar 11 menunjukkan bahwa walaupun tonjolan dibawah spesimen muncul pertama kali pada kolam lasan baja dengan sulfur tinggi, namun peningkatan durasi penyalaan busur memicu kehadiran tonjolan yang lebih besar pada spesimen baja dengan sulfur rendah.

Gambar 12 menunjukkan makrografi kolam lasan dengan perbedaan kadar sulfur yang diperoleh dengan peleburan dengan busur stasioner dengan arus 70 A. Bagian atas dan bawah dari gambar masing-masing menunjukkan diameter dan derajat penjebolan kolam lasan. Gambar 12a dan $12 \mathrm{~b}$ adalah hasil percobaan yang dilakukan pada baja 316 T dan 316R dengan durasi penyalaan busur 3 detik, sedangkan Gambar 12c dan 12d merupakan hasil percobaan dengan durasi penyalaan busur 9 detik. Bisa diamati dari gambar bahwa ketika durasi penyalaan busur 3 detik, diameter kolam lasan baja 316T lebih kecil dari baja 316R; derajat penjebolan kolam lasan juga tampak lebih besar (Gambar 12a). Sebaliknya, ketika durasi penyalaan busur 9 detik, diameter kolam lasan baja 316T sedikit lebih besar dan derajat penjebolan menjadi lebih kecil (Gambar 12c).

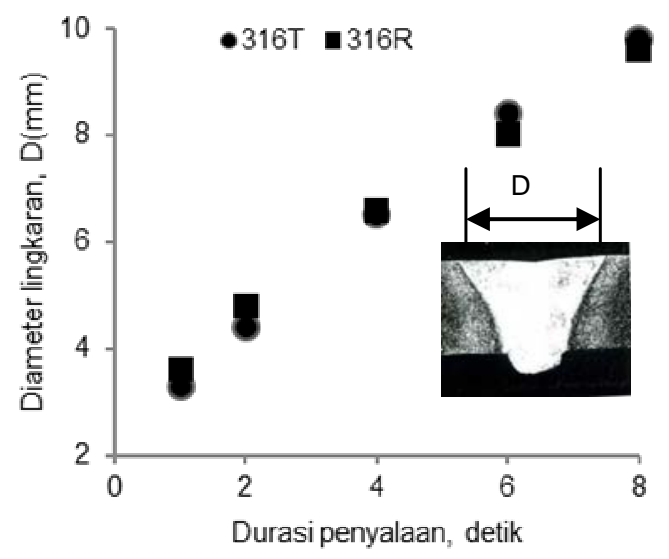

Gambar 10. Diameter Lingkaran Kolam Lasan Hasil Penyalaan Busur pada Arus $80 \mathrm{~A}$

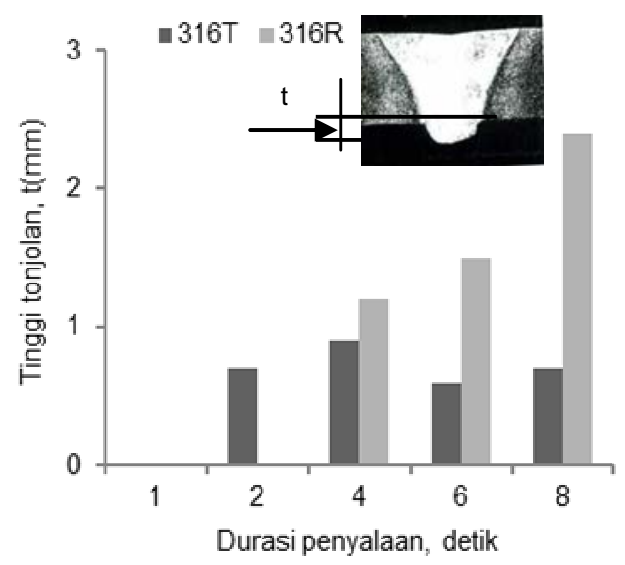

Gambar 11. Tinggi Tonjolan di Bawah Spesimen Kolam Lasan Hasil Penyalaan Busur pada Arus 80 A
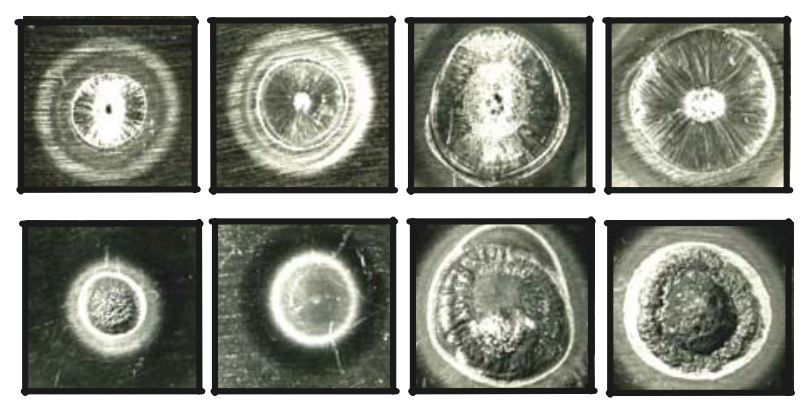

(a) $316 \mathrm{~T}, 3$ detik

(b) $316 \mathrm{R}, 3$ detik
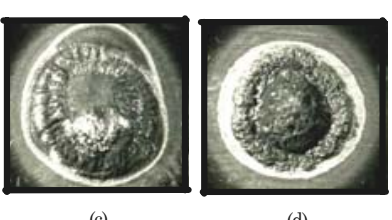

$316 \mathrm{~T}, 9$ detik

316R, 9 detik

Gambar 12. Makrografi Kolam Lasan Hasil Penyalaan Busur Baja dengan Arus 70 A dan Durasi Penyalaan 3 dan 9 Detik. Gambar atas menunjukkan diameter kolam lasan. Gambar bawah menunjukkan tonjolan pada bagian bawah specimen 
Dengan melihat keseluruhan hasil yang diperoleh, bisa dinyatakan bahwa peleburan yang dilakukan dengan arus yang relatif rendah menghasilkan penetrasi baja 316T yang lebih dalam dan diameter kolam lasan yang lebih kecil. Peningkatan arus tidak merubah kecenderungan ini kecuali ketika durasi penyalaan busur menjadi lebih tinggi. Fenomena ini merupakan akibat dari gradien termal dari tegangan permukaan positif pada baja dengan sulfur tinggi yang mengarahkan aliran cairan menuju bagian tengah kolam lasan dan memicu terbentuknya kolam lasan sempit dan dalam.

Perlu diperhatikan bahwa peningkatan arus dan durasi penyalaan busur, pada suatu rentang tertentu, bisa merubah kecenderungan pengaruh dari sulfur ini. Tampak pada gambar bahwa ketika arus dan durasi penyalaan berubah menjadi lebih besar, derajat penjebolan kolam lasan baja dengan sulfur tinggi menjadi lebih kecil ketimbang baja sulfur rendah; diameter kolam lasan juga menunjukkan harga yang lebih besar. Hipotesis yang bisa diajukan untuk menjelaskan hal ini adalah bahwa perubahan dari morfologi kolam lasan itu terkait dengan temperatur dalam kolam lasan dan variasi karakteristik busur.

Temperatur kolam lasan meningkat dengan peningkatan arus dan durasi penyalaan busur. Ketika harga arus dan durasi ini mencapai suatu ambang tertentu, temperatur yang tinggi pada kolam lasan mampu merubah gradien termal tegangan permukaan menjadi negatif. Dengan demikian arah aliran cairan akan sama, apakah peleburan dilakukan pada baja dengan sulfur tinggi atau rendah. Morfologi kolam lasan tidak lagi ditentukan oleh arah aliran cairan, tapi lebih ditentukan oleh fenomena yang lain.

Variasi komposisi kimia baja mempengaruhi karakteristik busur pada saat peleburan. Bisa diamati bahwa anode spot kolam lasan baja dengan sulfur tinggi lebih besar ketimbang baja sulfur rendah (bandingkan luasan bagian yang berbutirbutir pada bagian tengah kolam lasan pada gambar 12 a dan 12b serta gambar 12c dan 12d). Anode spot yang lebih besar ini menunjang distribusi energi melalui permukaan lebih besar yang memicu terbentuknya kolam lasan yang lebih luas dan lebih melebar baik pada permukaan spesimen maupun pada bagian bawahnya. Sebaliknya, anode spot yang lebih kecil pada baja dengan sulfur rendah memicu konsentrasi energi pada daerah yang lebih sempit yang memicu terbentuknya kolam lasan dengan diameter lebih kecil dan penjebolan lebih besar pada bagian bawah spesimen. Bisa disebutkan juga, bahwa pada saat terjadi penjebolan spesimen, tegangan permukaan yang lebih besar dari baja dengan sulfur rendah memicu permukaan yang lebih kecil dari tetes-tetes logam, yang dengan demikian menghasilkan tonjolan yang lebih panjang.
Dengan melihat hasil yang diperoleh, bisa disimpulkan adanya fenomena yang menarik tentang pengaruh dari elemen tensio-aktif pada pembentukan kolam lasan. Kandungan elemen tensio-aktif yang besar dalam baja tidak menghasilkan penetrasi yang lebih dalam kecuali ketika temperatur kolam lasan berada dibawah temperatur maksimal tertentu. Pengaruh yang berlawanan bisa terjadi ketika temperatur kolam lasan melampaui temperatur maksimal ini.

Dari aspek pengembangan industri, hasil penelitian ini bisa bermanfaat untuk aplikasi pemilihan material untuk pengelasan. Sifat mampu las dari baja yang terkait dengan morfologi lasan bisa dievaluasi dengan mengadakan pengujian dengan busur diam, dengan arus dan durasi penyalaan busur yang sudah ditentukan sebelumnya. Penerimaan atau penolakan material bisa dilakukan setelah pengamatan dan pengukuran diameter kolam lasan. Pada pengelasan pelat yang relatif tipis, penjebolan pada bagian bawah spesimen juga bisa menjadi obyek evaluasi. Percobaan ini bisa digunakan sebagai suatu prosedur pengujian kelayakan material untuk proses pengelasan yang sejauh ini sering menimbulkan masalah.

\section{KESIMPULAN}

Studi tentang kekasaran permukaan kolam lasan baja tahan karat 316 dengan kadar sulfur yang berbeda menunjukkan bahwa pengelasan baja dengan sulfur tinggi menampilkan permukaan yang lebih berombak dan kekasaran yang lebih tinggi. Hal ini terkait dengan aliran cairan ke arah dalam yang menimbulkan turbulensi dan kekasaran permukaan yang tinggi. Terjadinya turbulensi ini memicu pembentukan kolam lasan yang lebih dalam dan sempit yang ditunjukkan dengan penetrasi yang dalam dan rasio penetrasi dan lebar lasan P/L yang besar. Diamati adanya korelasi positif antara kekasaran permukaan dan Rasio P/L. Kekasaran permukaan yang lebih besar mengarah pada harga P/L yang lebih besar pula.

Studi tentang variasi morfologi kolam lasan dengan penyalaan busur menunjukkan bahwa pengaruh positif sulfur terhadap penetrasi dan rasio $\mathrm{P} / \mathrm{L}$ merupakan fungsi dari arus dan durasi penyalaan busur. Harga yang lebih besar dari parameter-parameter ini meningkatkan temperatur kolam lasan yang mengurangi efek positif dari sulfur. Pada kondisi ini, pembentukan kolam lasan lebih banyak ditentukan oleh karakteristik busur yang ditampilkan dengan variasi anode spot.

Kolam lasan baja tahan karat dengan sulfur tinggi tidak menunjukkan diameter yang lebih kecil dan penetrasi yang lebih dalam kecuali ketika arus dan durasi penyalaan busur relatif rendah. Ketika arus dan durasi penyalaan busur melampaui suatu harga tertentu, pengaruh dari sulfur menjadi tidak 
berarti. Kolam lasan baja dengan sulfur rendah malah menunjukkan diameter yang lebih kecil dan penetrasi yang lebih dalam; tonjolan lebih ekstensif diamati ketika kolam lasan mengalami penjebolan. Keberadaan dari anode spot yang lebih kecil dan tegangan permukaan yang lebih besar menjelaskan adanya penetrasi yang lebih besar ini.

Dari aspek pengembangan industri, hasil penelitian ini bisa dimanfaatkan untuk aplikasi yang sangat penting. Penyalaan dengan busur stasioner dengan arus dan durasi yang dikendalikan bisa digunakan untuk menentukan kelayakan atau sifat mampu las suatu material untuk proses pengelasan.

\section{DAFTAR PUSTAKA}

1. Binard,J., Chabenant, A., Etudes des parametres Definissant le bain de fusion, Soudage et Technique Connexes, Janvier-Fevrier, 1980.

2. Aidun, D.K., Martin, S.A., "Effect of Sulfur and Oxygen on Weld Penetration of High-purity Austenitic Stainless Steels", Journal of Materials Engineering and Performance, Volume 6, Number 4, pp. 496-502. 1997.

3. Heiple, C.R., Roper, J.R., "Mechanism for Minor Elemen effect on GTA Fusion Zone geometry", Welding Journal, April, Res. Supp. 97s-102s. 1982.

4. Fautrelle, Ecoulement dans le bain metallique en procede de soudage de TIG, Soudage et Technique Connexes, Janvier-Fevrier, 1980.
5. Heipple, C. R., Roper, J. R., "Effect of Selenium on GTAW Fuison Zone Geometry", Welding Journal, August, 1981.

6. Heipple, C. R.,Roper, J. R., Effect of Minor elements on GTAW Fusion Zone Shape, Trend in Welding Research in The USA, pp 489 - 520, ASM, Metal Park, Ohio, 1981.

7. Burgard, P., Heipple, C. R., "Interaction between Impurities and Welding Parameters in Determining GTA Weld Shape”, Welding Journal, June, Res. Supp. 150s-155s. 1986.

8. Kou, S., Wang, Y.H., "Weld Pool Convection and its Effect", Welding Journal, March, Res. Supp. 63s - 70s. 1986.

9. K. C. Mills, K. C., Keene, B. J., Brooks, R. F., Shirali, A.,"Marangoni Effects in Welding", Philosophical Transactions: Mathematical, Physical and Engineering Sciences, Vol. 356, No. 1739 , pp. 911-925. 1998.

10. Shanping, L., Fujii, H., Nogi, K., "Marangoni Convection and Weld Shape Variations in $\mathrm{Ar}-\mathrm{O}_{2}$ and $\mathrm{Ar}-\mathrm{CO}_{2}$ Shielded GTA Welding", Materials science \& engineering, Vol. 380, pp. 290-297. 2004.

11. Shanping, L., Fuji, H., Nogi, K, Marangoni Convection and Gas Tungsten Arc Weld Shape Variations on Pure Iron Plates", ISIJ International, Vol. 46, 2006.

12. Shahab, A., "Pengaruh Belerang Terhadap Aliran dan Morfologi Lasan Baja tahan Karat", Majalah Iptek ITS, Volume 4. 1993. 